\title{
Małgorzata Góralska: Piśmienność i rewolucja cyfrowa. Wrocław: Wydaw. Uniwersytetu Wrocławskiego, 2012, ss. 319. Seria Acta Universitatis Wratisla- viensis 3454. ISSN 0239-6661. ISBN 978-83-229-3343-5
}

Wydana już ponad półtora roku temu książka Małgorzaty Góralskiej pt. Piśmienność i rewolucja cyfrowa, jest pierwszą w polskim piśmiennictwie bibliologicznym próbą syntetycznego ujęcia przemian, zachodzących współcześnie w formach i narzędziach komunikacji piśmiennej oraz w związanych z nimi formach uczestnictwa w obiegu treści kulturowych i naukowych. Przemiany te autorka określa mianem „przystosowywania komputerów do pełnienia funkcji narzędzia piśmienności”, a analizę tego postępującego nadal procesu wpisuje w ramy teoretyczne bibliologii funkcjonalnej. Proces ten, stanowiąc jeden z najbardziej eksponowanych składników kształtowania współczesnej cywilizacji, doprowadził do obecnie obserwowanych i szeroko, a czasem emocjonalnie, dyskutowanych głębokich i powszechnych zmian w tworzeniu, dystrybuowaniu i wykorzystywaniu rezultatów ludzkiej aktywności intelektualnej, zapisanych w postaci tekstowej. Proces ten i kompleks towarzyszących mu i ewokowanych przez niego zjawisk M. Góralska uznaje za dokonującą się współcześnie rewolucję medialną, poddając ją holistycznemu oglądowi (w książce używa niezbyt trafnego określenia „spojrzenie globalne”) i porównując z wcześniejszymi tego typu fundamentalnymi przemianami, spowodowanymi przez odkrycie pisma i wynalazek druku. Te zestawienia i porównania służą wyodrębnieniu i wskazaniu istoty przemian implikowanych przez technologię komputerową dla współczesnej komunikacji piśmiennej.

W piśmiennictwie, zarówno światowym jak i polskim, problematyka rewolucji cyfrowej podejmowana była już wielokrotnie, czyniono to jednak dotąd albo z punktu widzenia przemian samej technologii komputerowej, albo transformacji mediów i komunikacji społecznej, albo wreszcie w kontekście przemian społecznych określanych jako kształtowanie społeczeństwa informacyjnego, czy też społeczeństwa sieciowego. W piśmiennictwie bibliologicznym i informatologicznym dotychczas skupiano z kolei uwagę na wybranych obszarach przemian powodowanych przez rozwój technologii komputerowej, np. w komunikacji naukowej, wyszukiwaniu informacji czy działalności bibliotecznej. Książka M. Góralskiej, z jednej strony zogniskowana na problemie komunikacji piśmiennej, a z drugiej dążąca do pełnego zobrazowania zjawisk związanych z przekształcaniem tej komunikacji pod wpływem postępującej informatyzacji, wnosi więc zupełnie nowe spojrzenie na tę problematykę, po raz pierwszy ujmując ją w kategoriach teoretycznej refleksji o prawidłowościach rządzących procesami rozwojowymi piśmienności i prowadząc do ważnych konstatacji, dotyczących uniwersalności i wielowymiarowości kultury książki.

Ponad 300-stronicowa monografia ma klarowną i przemyślaną budowę. Zasadnicza treść książki zorganizowana jest w trzech częściach. Około 40-stronicowe części pierwsza i trzecia mają charakter syntetyzującej refleksji teoretycznej. Blisko 200-stronicowa część druga zawiera obszerną analizę rozwoju technologii komputerowej, przeprowadzoną z perspektywy badań nad piśmiennością. Prezentację rozważań autorka poprzedziła wstępem, wyjaśniając w nim koncepcję książki, cel i metodę przedstawionych analiz oraz krótko omawiając zawartość kolejnych części. W zakończeniu książki zrekapitulowała natomiast swoje najważniejsze ustalenia, zwracając przy tym uwagę na problemy badawcze, które wymagają dalszych analiz i wyjaśnień. Monografię zamyka wykaz skrótów, bibliografia załącznikowa obejmująca ponad 300 publikacji w językach polskim i angielskim, wykaz 54 dodatkowych źródeł internetowych, starannie opracowane indeksy nazwisk oraz nazw produktów i usług komputerowych, wreszcie - streszczenie książki w języku angielskim. 
Pierwsza część monografii, zatytułowana Piśmienność, piśmiennictwo i formy jego istnienia wyznaczone przez kolejne rewolucje medialne, podzielona na cztery rozdziały, służy dwóm celom: wyjaśnieniu kluczowych dla dalszych rozważań pojęć piśmienności i rewolucji medialnej jako kategorii badawczych oraz prezentacji za pomocą tych kategorii dwóch wcześniejszych rewolucji medialnych - greckiej rewolucji piśmiennej i rewolucji zainicjowanej wynalazkiem Gutenberga. Piśmienność M. Góralska interpretuje szeroko, jako praktykę tworzenia, upowszechniania i użytkowania utrwalonych za pomocą pisma przekazów językowych, stanowiącą czynnik kształtujący kulturę i umysłowość człowieka. Praktyka ta genetycznie związana jest z piśmiennictwem, czyli zasobami językowych przekazów utrwalonych za pomocą pisma, najpierw manualnie (w postaci rękopiśmiennej), później mechanicznie (druk) i wreszcie elektronicznie (w postaci zapisów cyfrowych). Rewolucje medialne dotyczą zmian zachodzących w praktykach piśmienności w skali zarówno indywidualnej, jak i zbiorowej. Określanie rewolucja przełomowych zmian, które zachodzą w formach i sposobach komunikowania społecznego nie jest nowe, wielu autorów (np. M. McLuhan, A. Toffler, Ch. Vandendrope, J. Pirożyński, T. Goban-Klas, M. Hopfinger, R. Fidler) używa go właśnie w opisie przechodzenia od jednych do kolejnych upowszechniających się środków przekazu wiedzy i tradycji, skupiając przy tym uwagę głównie na zmianie technologii. Wyodrębniając, śladem innych autorów, trzy rewolucje medialne (piśmienną, druku i cyfrową), również M. Góralska ich cechy podstawowe opisuje w kategoriach technologicznych, odwołując się do teorii Terje Hillesunda. Pojęciem rewolucji medialnej jako kategorią badawczą operuje jednak w sposób szerszy, wzorowany na koncepcji rewolucji naukowych Thomasa Kuhna. Autorka definiuje rewolucję medialna jako pewien model konfiguracji zjawisk i procesów, które w sposób trwały decydują o przekształceniach sposobów istnienia piśmiennictwa najważniejszych dla transferu treści kulturowych i naukowych oraz całego systemu komunikacji, obejmującego produkcję, udostępnianie i odbiór treści wprowadzanych do obiegu społecznego. Poddając analizie zjawisko rewolucji medialnej, M. Góralska skupia więc uwagę na całym kompleksie charakteryzujących je czynników: jego przyczynach (kryzys, zmiana technologiczna, konflikt), specyfice (zasady użytkowania dotychczasowego medium powszechnego, role uczestników komunikacji, zróżnicowana funkcjonalność dotychczasowego systemu komunikacji, ograniczenia tego systemu i rosnąca ich świadomość społeczna oraz próby udoskonalania systemu przez innowacje technologiczne) oraz skutkach (upowszechnienie nowej technologii, przejmowanie przez nią funkcji pełnionych przez dotychczasowe media, dostosowywanie reguł systemu komunikacji do nowego medium i jego rozwój, zrównoważenie bilansu zysków i strat dokonanej transformacji). W ten sposób najpierw, odwołując się do prac badaczy piśmienności (m.in. W. Onga, E.A. Havelocka, J. Goody'ego, D.R. Olsona), szkicuje obraz pierwszej rewolucji medialnej, związanej z upowszechnieniem między VII a V w p.n.e. pisma greckiego, które doprowadziło do przejścia od komunikacji oralnej do komunikacji piśmiennej. Następnie tą samą metodą, odwołując się do badań i spostrzeżeń historyków książki drukowanej (m.in. A. Briggsa i P. Burke'go, A. Blair, J. Pirożyńskiego, B. Bieńkowskiej, K. Migonia, E. Potkowskiego, E.L. Eisenstein, L.D. Reynoldsa i N.G. Wilsona) prezentuje rewolucję Gutenberga. W taki sposób w pierwszej części książki autorka demonstruje swoją teorię rewolucji medialnych i koncepcję analizowania najważniejszej dla jej rozważań, dokonującej się współcześnie rewolucji cyfrowej.

Najobszerniejsza i dla celu rozprawy zasadnicza część druga książki pt. Rewolucja cyfrowa jako rewolucja medialna zawiera szczegółową, bogatą faktograficznie analizę przyczyn i specyfiki zmian wywołanych w ciągu ostatnich blisko 70 lat przez rozwój i upowszechnianie się technologii komputerowej jako medium komunikacji piśmiennej. Jest to wywód bardzo dobrze przemyślany i przekonujący. Trafnym zabiegiem metodologicznym autorki było zastąpienie często stosowanego w takich omówieniach chronologicznego opisu przebiegu analizowanych zmian, porządkiem rozważań według najważniejszych aspektów rewolucji medialnej naszych czasów, kluczowych dla charakteru przemian w komunikacji piśmiennej. Tę część książki otwiera więc wstęp, w którym M. Góralska jako przyczyny rewolucji cyfrowej wskazuje słabnącą wydajność systemu komunikacji opartego na druku 
w zapewnianiu dostępu do treści zawartych w piśmiennictwie, które jest coraz bogatsze ilościowo i coraz bardziej szczegółowe, a zarazem wyspecjalizowane tematycznie. Potwierdzeniem coraz silniej odczuwanej potrzeby rozwiązania narastającego w związku z tym kryzysu informacyjnego są, według autorki, pochodzące z pierwszej połowy XX wieku wizje, pomysły i próby przeorganizowania obiegu piśmiennictwa, w którym wykorzystywane byłyby zupełnie nowe narzędzia, umożliwiające mechanizację, a następnie automatyzację procesów selekcji informacji z coraz większych zasobów tekstowego zapisu wiedzy (P. Otlet, H.G. Wells, V. Bush).

W następujących po tym wstępie sześciu rozdziałach M. Góralska omawia kolejne aspekty dojrzewania koncepcji technologii komputerowej do roli nowego narzędzia piśmienności. W rozdziale pierwszym, zatytułowanym „Oblicza technologii komputerowej”, przytaczając prace pionierów tej technologii, objaśnia, jak z narzędzi pierwotnie przeznaczonych do skomplikowanych obliczeń matematycznych i przetwarzania informacji w wielkich zbiorach danych, z którymi równocześnie eksperymentowano $\mathrm{w}$ badaniach nad sztuczną inteligencją i przetwarzaniem języka naturalnego, komputery i ich sieci stały się powszechnym medium komunikacyjnym. Interesujące jest tu w szczególności przypomnienie pierwszych koncepcji przekształcenia dotychczasowego systemu transferu wiedzy w system, który zapewnić ma powiększenie możliwości intelektualnych człowieka, dostarczając mu wiedzę przetworzoną i dostosowaną do jego celów (J.C.R. Licklinder, D. Engelbart, T. Nelson). Omawiając pierwsze zastosowania komputerów w zakresie przetwarzania informacji, autorka zwraca uwagę na „wątek” najwcześniejszych prac związanych z informatyzacją instytucji książki, a ściślej - najpierw mechanizacją i automatyzacją przetwarzania danych bibliograficznych, a następnie bibliotecznych katalogów i bibliotecznych procesów administracyjnych. Wpisanie historii bibliograficznych baz danych i bibliotecznych systemów komputerowych w szerszy kontekst uwarunkowań i koncepcji rozwijania technologii komputerowej w latach 60. i 70. XX wieku, pokazanie rodowodu tych projektów i ich powiązania z innymi ówczesnymi projektami w zakresie przetwarzania informacji, świetnie pozwala uchwycić istotę problemów, z którymi boryka się współczesne bibliotekarstwo i które bardzo często nie są właściwie rozumiane.

W rozdziale drugim pt. „Znaczenie wybranych środowisk dla kierunków rozwoju i obszarów zastosowań komputerów", autorka omawia z kolei wpływ zaangażowania wojska, biznesu oraz środowiska naukowego i akademickiego na rozwój technologii komputerowej i jej upowszechnienie jako narzędzia komunikacji społecznej. Choć zagadnienia te znane są z analiz innych autorów (np. M. Castells, P. Gawrysiak), to ich znaczenie dla przebiegu cyfrowej rewolucji medialnej uzasadnia przypomnienie i ocenę w tej części książki najważniejszych faktów dotyczących tego aspektu. Omawiając działalność środowisk hakerskich i akademickich, związanych z zapewnieniem swobodnego rozwoju oprogramowania i wolnego dostępu do treści cyfrowych, słusznie autorka podkreśliła ich decydującą rolę w demokratyzacji technologii komputerowej i nadaniu jej wymiaru „technologii wolności”. Znaczenie dla cyfrowej rewolucji medialnej takiej właśnie postawy środowisk naukowych doskonale ilustruje fakt udostępnienia do powszechnego użytku przez Tima Bernersa-Lee jego wynalazku, pierwotnie stworzonego dla potrzeb CERN, który przyjął postać sieci World Wide Web. Bez sieci WWW dzisiaj trudno byłoby sobie wyobrazić jak funkcjonowałaby powszechna komunikacja w Internecie.

W rozdziale trzecim pt. „Przystosowanie komputerów do roli narzędzia piśmiennictwa”, M. Góralska przedstawia analizę znaczenia komunikacji za pomocą tekstu pisanego dla rozwoju technologii komputerowej oraz wpływu tradycyjnej kultury książki na przekształcanie tej technologii $\mathrm{w}$ uniwersalne i powszechne medium piśmienności. Zgodnie z przyjętą $\mathrm{w}$ rozprawie metodą, na proces przystosowywania komputerów do tej roli, autorka patrzy holistycznie i wieloaspektowo, wskazując zmiany wprowadzane zarówno w sprzęcie komputerowym, jak i w aplikacjach programowych, zmieniające się z czasem możliwości techniczne i zadziwiająco silne oddziaływanie tradycyjnej struktury i funkcjonalności książki, na koncepcje doskonalenia narzędzi komputerowych przez odtwarzanie właściwości książki w środowisku cyfrowym. M. Góralska prezentuje 
takie zjawiska, widoczne w trzech obszarach: (1) wykorzystywania komputerów jako urządzeń do pisania, dystrybucji i czytania tekstu; (2) redagowania dokumentów tekstowych i hipertekstowych oraz (3) użytkowania elektronicznych zapisów jako nowej formy e-książki odczytywanej na coraz bardziej funkcjonalnych czytnikach (Kindle).

Rozdział czwarty poświęcony jest wykorzystywaniu komputerów do przetwarzania danych tekstowych znowu w trzech, wybranych przez autorkę obszarach: (1) tworzenia konkordancji i indeksów, z którym wiążą się pierwsze zastosowania technologii komputerowej w badaniach językoznawczych i literaturoznawczych, i które dało początek systemom automatycznego indeksowania; (2) rozwoju bibliograficznych i pełnotekstowych baz danych oraz narzędzi ich przeszukiwania; (3) indeksowania zawartości książek drukowanych, które wiąże się z projektami digitalizacji piśmiennictwa i umożliwienia na szeroką skalę komputerowego pełnotekstowego przeszukiwania wielkich zasobów cyfrowo zapisanego piśmiennictwa, za pomocą wyszukiwarek internetowych (projekty Google Print i Google Books).

Dwa ostatnie rozdziały części obejmującej analizę cyfrowej rewolucji medialnej, M. Góralska poświęca kwestii udostępniania piśmiennictwa w środowisku cyfrowym i toczonej od końca lat 70. XX wieku dyskusji o przyszłości książki drukowanej i zastąpieniu jej przez piśmienną komunikację cyfrową. Proces zastępowania książki drukowanej elektronicznym zapisem tekstów autorka prezentuje na trzech różnych przykładach: encyklopedii, bibliotek cyfrowych i innych kolekcji dokumentów elektronicznych oraz nowych form literackich, kształtowanych w środowisku cyfrowym. Pierwszy przykład dobrze ilustruje - z jednej strony - dostosowanie współczesnej technologii komputerowej do potrzeb udostępniania wiedzy encyklopedycznej, jej upowszechniania i aktualizowania, a z drugiej wielość podejmowanych w tym zakresie inicjatyw, których trwałość ostatecznie zapewniona została albo przez zaangażowanie się w tę działalność wielkich wydawców encyklopedii tradycyjnych (np. Britannica Online), albo prężny ruch społecznościowy (Wikipedia). Udostępnianie wiedzy encyklopedycznej w sieciowym środowisku cyfrowym dobrze też demonstruje nowe zjawiska, możliwości i problemy związane $\mathrm{z}$ transferem wiedzy w warunkach niekontrolowanego przez autorytety jej tworzenia oraz społecznych oczekiwań nieograniczonej dostępności tej wiedzy. Z kolei przykład tworzenia kolekcji cyfrowych dokumentów pokazuje wykorzystywanie podejścia opartego na tradycyjnej metodyce bibliotekarskiej do organizowania dostępu do zdigitalizowanych form piśmiennictwa pierwotnie drukowanego, którego kolekcje tworzone są celowo dla upowszechniania dziedzictwa kulturowego we współczesnych społeczeństwach. Te zwykle starannie dobrane i opracowane kolekcje stanowią obecnie zasób już znaczący ilościowo i bez wątpienia przyczyniają się do włączania w elektroniczny obieg coraz większej części piśmiennictwa tradycyjnego. Nie kwestionując więc wartości tych projektów, trzeba jednak zauważyć, że największy wpływ na wprowadzenie piśmiennictwa drukowanego do cyfrowej komunikacji piśmiennej mają projekty i działania firmy Google, które mimo różnych kontrowersji już dziś zapewniają (wprawdzie słabo uporządkowany) dostęp do największych zasobów zdigitalizowanego i oryginalnie digitalnego piśmiennictwa.

W kilkunastostronicowym omówieniu kwestii kształtowania się tzw. literatury elektronicznej, M. Góralska ukazuje natomiast wpływ technologii komputerowej na formowanie się nowych form literackich, takich jak np. powieść hipertekstowa (hiperfikcja), twórczość hipermedialna, fikcja interaktywna, narracja lokacyjna, twórczość cybertekstowa czy poezja flaszowa. Ich upowszechnienie potwierdzić mogłoby, że technologia komputerowa osiągnęła status prawdziwie uniwersalnego narzędzia piśmienności, wykorzystywanego nie tylko do udostępniania form piśmiennictwa ukształtowanych w tradycji pisma i druku, ale też w twórczości literackiej jako jej swoiste tworzywo, wpływając również na przeobrażenia praktyk lekturowych. Eksploracja możliwości komputerów w tym zakresie wyraźnie postępuje, choć trudno byłoby obecnie literacką twórczość elektroniczną uznać za trend dominujący we współczesnej literaturze. Kwestią otwartą pozostaje zatem to, w jakim stopniu technologia komputerowa zmieni twórczość literacką, ale jej wpływ na nią jest już widoczny. 
Opisane we wcześniejszych rozdziałach zjawiska skłaniają do dyskusji nad przyszłością książki drukowanej, której omówieniem M. Góralska zamyka rozważania zawarte w drugiej części książki. Uznaje ją za kolejny charakterystyczny rys dokonującej się rewolucji medialnej: spór między zwolennikami medium „starego" (m.in. T. Roszak, N. Postman, C. Stoll, U. Eco, M. Heim, P. Duguid, D. Kerckhove, A. Keen, A. Grafton) i entuzjastami medium „nowego” (np. J. Bolter, G. Landow, R. Coover, N. Negroponte, R. Kurzweil, K. Kelly, J. Weisberg). Autorka własnego stanowiska nie deklaruje, choć wydaje się przyjmować postawę racjonalizującą ten spór, wyrażoną przekonaniem, że odejście od druku na rzecz komputerów nie oznacza końca piśmienności, a jedynie zmianę jej oblicza i kształtowanie nowej formy książki.

W trzeciej, ostatniej części książki, autorka porządkuje wnioski z przeprowadzonej analizy przebiegu i cech charakteryzujących cyfrową rewolucję medialną, stosując w tym celu wcześniej przez siebie zaproponowany ogólny model rewolucji medialnej. Najpierw więc przypomina symptomy kryzysu systemu komunikacji opartej na druku, później najbardziej znaczące etapy kształtowania się innowacji technologicznej, która stała się podstawą nowego systemu komunikacji cyfrowej. Wiąże kolejne fazy rozwoju technologii komputerowej jako narzędzia komunikacji piśmiennej z narastaniem debaty o przyszłości książki drukowanej. Stawia tezę, że „system komunikacji elektronicznej od przełomu wieków funkcjonuje już w zasadzie w pełnym zakresie, to znaczy umożliwia tworzenie, przechowywanie, dystrybuowanie i odczytywanie dokumentów różnego typu wyłącznie w środowisku cyfrowym" (s. 246). Autorka zauważa wprawdzie, że system ten jeszcze rozwija się i jego pełne ukształtowanie zabrać może jeszcze długi czas, ale uznaje, że jest to już moment, kiedy można podjąć analizę efektów rewolucji cyfrowej w komunikacji piśmiennej. Należą do nich zmiany w doświadczaniu przez uczestników komunikacji piśmiennej czasu i przestrzeni, którym M. Góralska poświęciła odrębną książkę, wydaną trzy lata wcześniej (Książki, nowe media i ich czasoprzestrzenie, Warszawa 2009). W Piśmienności i rewolucji cyfrowej analizę tych efektów przeprowadza natomiast w odniesieniu do czterech prawidłowości obserwowanych już przez badaczy dwóch wcześniejszych przemian systemów komunikacji społecznej - trzy pierwsze wskazuje za Jackiem Goody'm, czwarte jest jej własną obserwacją. Pierwszą prawidłowość stanowi zjawisko narastania zasobów piśmiennictwa, które M. Góralska określa multiplikacją. Drugą - zjawisko zwiększania się społecznej dostępności piśmiennictwa, określone jako demokratyzacja. Trzecim - mnożenie się zastosowań pisma, określone dywersyfikacją. Prawidłowością czwartą, którą autorka uważa za najistotniejszą dla specyfiki rewolucji medialnych jest technicyzacja, czyli narastanie złożoności instrumentarium piśmienności. Analiza tych prawidłowości przedstawiona w kolejnych czterech rozdziałach ostatniej części książki, zgodnie z założeniem autorki, pokazuje jak w ogóle rewolucje medialne wpłynęły na rozwój piśmienności i jak rewolucja cyfrowa wpisuje się w ten generalny model zmian zachodzących w komunikacji piśmiennej.

Książka Małgorzaty Góralskiej Piśmienność i rewolucja cyfrowa jest lekturą bardzo ciekawą, niezwykle bogatą faktograficznie i pobudzającą do refleksji nie tylko o przemianach, ale też o uniwersalizmie komunikacji piśmiennej. Na podstawie analizy literatury przedmiotu i bogatego materiału źródłowego, czerpanego przede wszystkim z archiwów cyfrowych licznych, w większości amerykańskich, instytucji i organizacji zaangażowanych w rozwój technologii cyfrowej oraz zasobów Internet Archive, autorka zgromadziła w nim imponujący materiał, który w sposób wielostronny dokumentuje przebieg i specyficzne cechy transformacji systemu komunikacji piśmiennej, dokonującej się w wyniku jej cyfryzacji. Zaproponowała oryginalną koncepcję holistycznego spojrzenia na mechanizmy rozwoju komunikacji społecznej za pomocą słowa pisanego oraz kategoryzacji zachodzących w niej przeobrażeń. Metoda ta umożliwiła jej przedstawienie syntezy tej problematyki i wykazanie ciągłości komunikacji piśmiennej. Natomiast zdefiniowanie pojęcia rewolucji medialnej jako zjawiska, które decyduje o podstawowych sposobach istnienia piśmiennictwa oraz kształtuje warunki jego produkcji, udostępniania i odbioru, pozwoliło autorce wyjaśnić charakter zmian powodowanych przez innowacje technologiczne o rewolucyjnym potencjale. Warto też zwrócić uwagę na 
konstatacje autorki dotyczące występowania w historii technologii komputerowej zagadnień związanych z piśmiennictwem i jego obiegiem w społeczeństwie oraz z komunikacją za pomocą słowa pisanego między ludźmi i między człowiekiem a komputerem. Świetnie ukazują one przenikanie się i splatanie w badaniach nad współczesną rzeczywistością komunikacyjną zainteresowań bibliologów, informatologów i historyków informatyki.

\author{
Barbara Sosińska-Kalata \\ Instytut Informacji Naukowej i Studiów Bibliologicznych \\ Uniwersytet Warszawski
}

Nadestano: 30.01.2014.

\title{
Władysław Marek Kolasa: Historiografia prasy polskiej (do 1918 roku) - naukometryczna analiza dyscypliny (1945-2009). Kraków: Wydaw. Nauk. Uniwersytetu Pedagogicznego, 2013, ss. 528 + CD. Seria „Prace Monograficzne” 678. ISSN 0239-6025. ISBN 978-83-7271-843-1
}

W swojej monografii Władysław Marek Kolasa poddał wieloaspektowej analizie bibliometrycznej dorobek badawczy i osiągnięcia historyków prasy polskiej z lat 1945-2009. Uwzględnił publikacje, w których omawiali oni stan i rozwój polskiej prasy od jej początków do 1918 r. Autor cały ten okres podzielił na dwa działy główne: $\mathrm{w}$ pierwszym $\mathrm{z}$ nich objął badaniami zbiór prac nad dawną prasą polską (tj. do 1864 r.), w drugim zaś - nad prasą doby popowstaniowej (1864-1918). Zastosował więc podział według okresów historycznych, dodatkowo osobno wydzielił prasę polską za granicą (którą następnie włączył do odpowiednich działów głównych), opracowania ogólne, historię radiofonii i telewizji, metodologię badań historycznoprasowych. W obrębie poszczególnych działów zastosował dalsze podziały, zgodnie ze specyfiką i zawartością działów głównych. W sumie książka składa się z trzech rozdziałów, dzielących się na podrozdziały. Pierwszy z nich szczegółowo objaśnia przyjęte przez autora założenia i metody badawcze, opis zasad budowy i zawartości opracowanej przez niego bazy danych (Indeks Cytowań Historiografii Mediów Polskich), która stała się podstawowym narzędziem do oceny analizowanej dyscypliny. Rozdział ten zawiera też hipotezy badawcze potwierdzone przez wstępne wyniki bibliometrycznej analizy zgromadzonego w bazie materiału. Dwa kolejne rozdziały łączą w sobie bardzo szczegółowe analizy stanu badań (piśmiennictwa) nad rozwojem polskiej prasy z wnikliwym obrazem historii prasy w całym omawianym okresie. Obszerne (29 stron) zakończenie pracy nie tylko zbiera wnioski wynikające z poprzednich rozdziałów, ale wprowadza też nowe ustalenia, związane z różnicami i podobieństwami w rozwoju badań nad prasą w obu omawianych przedziałach czasowych (do 1864 r. i po powstaniu styczniowym do końca I wojny światowej) oraz formułuje postulaty dotyczące podjęcia badań w obszarach słabo do tej pory rozpoznanych. Rozprawę uzupełnia bibliografia, która wyodrębnia prace metodologiczne (łączy tu metodologię badań bibliometrycznych, historycznych, prasoznawczych oraz uwzględnia prace z zakresu krytyki naukowej) oraz - w wyborze (ok. 600 pozycji) - opracowania z historii prasy polskiej wraz z dodatkowymi istotnymi danymi o każdej publikacji (oznaczenie jej przynależności do działu, liczba cytowań). Pełną bibliografię prac naukowych z zakresu historii prasy, liczącą 4553 pozycje, z których każda zawiera także ważne dane dodatkowe, dołączył autor na płycie CD. Rozprawę uzupełniają ponadto indeksy i wykazy: indeks uwzględnionych w pracy tytułów czasopism i gazet z lat 1501-1918; indeks osób wymienianych w tekście i przypisach dysertacji; spis tabel, wykresów, rysunków i map. Bardzo przydałby się również indeks przedmiotowy, gdyż harmonijnie połączyłby wielokrotnie poruszane w rozprawie wątki tematyczne, te same, choć odnoszące się do różnych okresów. 